Article

\title{
Electrochemically reduced graphene oxide with enhanced electrocatalytic activity toward tetracycline detection
}

\author{
Yanyan Xu a, Mingming Gao a,*, Guohui Zhang b, Xinhua Wang a, Jiajia Li a, Shuguang Wang a,\#, \\ Yuanhua Sang c \\ a Shandong Provincial Key Laboratory of Water Pollution Control and Resource Reuse, School of Environmental Science and Engineering, Shandong \\ University, Jinan 250100, Shandong, China \\ b Department of Chemistry, University of Warwick, Coventry CV 47 AL, United Kingdom \\ c State Key Laboratory of Crystal Materials, Shandong University, Jinan 250100, Shandong, China
}

\section{A R T I C L E I N F O}

Article history:

Received 23 April 2015

Accepted 3 July 2015

Published 20 November 2015

\section{Keywords:}

Electrochemically reduced graphene oxide

Electrochemical detection

Tetracycline

Electrocatalytic activity

Oxygen-containing functional groups

\begin{abstract}
A B S T R A C T
An electrochemically reduced graphene oxide sample, ERGO-0.8v, was prepared by electrochemical reduction of graphene oxide (GO) at $-0.8 \mathrm{~V}$, which shows unique electrocatalytic activity toward


V), GO, chemically reduced GO (CRGO)-modified glassy carbon electrode (GC) and bare GC electrodes. The redox peaks of TTC on an ERGO-0.8v-modified glass carbon electrode (GC/ERGO- $-0.8 \mathrm{~V}$ ) were within $0-0.5 \mathrm{~V}$ in a $\mathrm{pH} 3.0$ buffer solution with the oxidation peak current correlating well with TTC concentration over a wide range from 0.1 to $160 \mathrm{mg} / \mathrm{L}$. Physical characterizations with Fourier transform infrared (FT-IR), Raman, and X-ray photoelectron spectroscopies (XPS) demonstrated that the oxygen-containing functional groups on GO diminished after the electrochemical reduction at $-0.8 \mathrm{~V}$, yet still existed in large amounts, and the defect density changed as new $s p^{2}$ domains were formed. These changes demonstrated that this adjustment in the number of oxygen-containing groups might be the main factor affecting the electrocatalytic behavior of ERGO. Additionally, the defect density and $s p^{2}$ domains also exert a profound influence on this behavior. A possible mechanism for the TTC redox reaction at the GC/ERGO- $0.8 \mathrm{v}$ electrode is also presented. This work suggests that the electrochemical reduction is an effective method to establish new catalytic activities of GO by setting appropriate parameters.
\end{abstract}

(C) 2015, Dalian Institute of Chemical Physics, Chinese Academy of Sciences. Published by Elsevier B.V. All rights reserved.

\section{Introduction}

Tetracyclines (TTCs) are one of the most extensively used veterinary medicines for their broad antibacterial spectrum and low production cost. Currently, TTCs are increasingly applied in personal care products. The large consumption of this antibiotic inevitably leads to the existence of the unmodified parent compounds or metabolized products in surface water, groundwater and sewage treatment plants, which can be directly toxic or spread drug-resistant genes [1,2]. So far, several techniques and methods have been developed for the determination of TTC, including immunoassay, microbiological meth-

\footnotetext{
* Corresponding author. Tel: +86-531-88362802; Fax: +86-531-88364513; E-mail: mmgao@sdu.edu.cn

\# Corresponding author. E-mail: wsg@sdu.edu.cn

This work was supported by the National Natural Science Foundation of China (21007033) and the Fundamental Research Funds of Shandong University (2015JC017).
} 
ods, and chemical-physical techniques (e.g., high-performance liquid chromatography/glass carbon electrode and capillary zone electrophoresis) $[3,4]$. However, these are expensive, timeconsuming, or demand complicated sample pre-treatments. Most importantly, they are not suitable for in-situ or routine analysis.

Electrochemical methods are proposed to be promising for pollutant detection owing to their simple and reliable procedure, low cost, fast investigation, and high sensitivity [5,6]. It has been reported that TTC can be electrochemically oxidized by several materials, especially carbon nanotubes [7-11].

As a competitor to carbon nanotubes, graphene has exhibited superior performance in electrochemical sensor application [12]. However, graphene oxide (GO), as a precursor of graphene, has many oxygen-containing functional groups on the basal plane and the sheet edge, which lead to its insulation and disorder. These functional groups provide the unique chemical functionality of GO owing to its heterogeneous electronic structure, which contains a mixture of $s p^{2-}$ and $s p^{3}$-hybridized carbon atoms [13]. Owing to some unique characteristics, interest among researchers has increasingly shifted from investigating GO as a precursor for graphene to determining the properties of GO. It has been found that the oxygen-containing functional groups on the basal plane and sheet edge allow GO to interact with a wide variety of organic and inorganic materials. Furthermore, a more efficient reduction treatment for GO could result in further interesting properties by the creation of new $\mathrm{sp}^{2}$ clusters and the adjustment of surface functional groups through the removal of oxygen [14]. It is known that the electrochemistry of a variety of compounds is sensitive to surface defects and surface functional groups. Therefore, reduced GO may be potentially used as an electrocatalyst in various electrochemical reactions [12,15-18]. However, investigations on the development of graphene-based materials/devices for electroanalysis and electrocatalysis are still limited [15].

Among the different techniques in reduction chemistry, electrochemical reduction provides a green and fast method for GO reduction, and shows promise for controlling the extent and process of reduction [6,12,19,20]. Moreover, electrochemically reduced GO (ERGO) has shown a better performance than chemically reduced GO (CRGO) in several previous reports $[5,6,17,18,21]$. The tunability of the $s p^{2}$ and $s p^{3}$ fractions by the electrochemical reduction is a powerful way to tune its bandgap and transform GO from an insulator to a semiconductor [15]. The obtained functionalized graphene material has an abundance of structural defects and functional groups, which are beneficial for electrochemical applications [22,23]. Researchers have reported that the ERGO exhibits enhanced activity for the electrocatalytic reduction of $\mathrm{O}_{2}$ and $\mathrm{H}_{2} \mathrm{O}_{2}$, and higher electrochemical capacitance for the potential application in ultracapacitors [18] or other applications [24-26]. Most electrochemical reduction is performed at the potential of -1.0 to $-1.5 \mathrm{~V}$, where a variety of the oxygen-containing functional groups can be removed $[6,16,27]$. However, the electrocatalytic activity of GO may also disappear along with the functional groups.
In this work, the electrochemical reduction of GO was applied through cyclic voltammetry to adjust the surface defects and surface functional groups. The obtained ERGO shows unique electrocatalytic activity toward TTC detection compared with GO and CRGO. The structural features of ERGO, GO, and CRGO were investigated by Raman, Fourier transform infrared (FT-IR), and X-ray photoelectron spectroscopy (XPS) techniques, and were correlated with their electrochemical behavior toward TTC detection. The possible electrocatalytic mechanism of ERGO toward TTC oxidation was proposed.

\section{Experimental}

\subsection{Materials and instruments}

Graphite powder (99.95\% purity) was purchased from Aladdin (Shanghai, China). TTC was obtained from Sigma-Aldrich. Other chemicals, such as hydrazine hydrate and $\mathrm{N}, \mathrm{N}$-dimethylformamide (DMF), were all of analytical grade and obtained commercially. All the solutions were prepared using double-distilled water.

A whirlpool mixer (QL-901, Haimen Kylin-Bell Lab Instruments Co., Ltd) was employed to disperse TTC in $0.10 \mathrm{~mol} / \mathrm{L}$ sodium tartrate solutions $(\mathrm{pH}=3.0)$. The cyclic voltammetric (CV) experiments were performed on a CHI 760D electrochemical workstation (Chenhua Co., Shanghai, China) in a conventional three-electrode system, including a modified glassy carbon electrode (GC, $3 \mathrm{~mm}$ in diameter) as a working electrode, an SCE as a reference electrode, and a platinum plate (1 $\mathrm{cm} \times 1.5 \mathrm{~cm}$ ) as an auxiliary electrode. All the potential values were reported against SCE.

\subsection{Preparation of the modified electrode}

GO was synthesized from graphite powder (99\%, $40 \mathrm{~nm}$, Aladdin) by Hummers' method [28]. CRGO was obtained by the chemical reduction of GO, where GO was reduced by ammonia water and hydrazine hydrate. GO (50 mg) was first dispersed in $250 \mathrm{~mL}$ of water by ultrasonication. Consequently, $250 \mu \mathrm{L}$ of $25 \%$ ammonia water and $250 \mu \mathrm{L}$ of hydrazine hydrate were added to the solution. The solution was maintained at $95{ }^{\circ} \mathrm{C}$ in a water bath for $1 \mathrm{~h}$, followed by filtration and washing with water.

The GO-modified GC (GC/GO) electrode was prepared with a $5-\mu \mathrm{L}$ GO aqueous dispersion solution ( $0.05 \mathrm{wt} \%)$ dropped on the electrode, and then dried in air. A similar method was used to prepare the GC/CRGO electrode, with a 5- $\mu \mathrm{L}$ CRGO DMF dispersion solution ( $0.05 \mathrm{wt} \%$ ) dropped on the electrode. Prior to use, each of the modified electrodes was carefully rinsed with water to remove the loosely attached materials.

The GC/ERGO-0.8v electrode was obtained by electrochemical reduction of the GC/GO electrode. $\mathrm{CV}$ was applied to the GC/GO electrode in $0.1 \mathrm{~mol} / \mathrm{L}$ sodium tartrate buffer solutions in the potential range of -0.8 to $+1.4 \mathrm{~V}$ at a scan rate of $10 \mathrm{mV} / \mathrm{s}$ for five cycles, until the cyclic voltammetric curve was stable. The GC/ERGO-1.2v electrode was obtained by applying a potential in the range of -1.2 to $+1.4 \mathrm{~V}$ to the GC/GO electrode under 
the same conditions.

\subsection{Electrochemical measurements}

$\mathrm{CV}$ was applied in a series of $0.1 \mathrm{~mol} / \mathrm{L}$ sodium tartrate buffer solutions containing different TTC concentrations on the above prepared electrodes. The electrode was placed into a 0.1 $\mathrm{mol} / \mathrm{L}$ sodium tartrate buffer solution and scanned at a rate of $50 \mathrm{mV} / \mathrm{s}$ between -0.8 and $+1.4 \mathrm{~V}$ for four cycles after each experiment. The third cycle of the voltammogram was recorded for each sample.

\subsection{Physical characterizations}

A 5- $\mu \mathrm{L}$ GO aqueous dispersion solution was dropped on the conductive glass as the sample, and then CV was used to reduce GO, which was characterized by FT-IR, Raman, and XPS. XPS measurements were carried out on a Thermo ESCALAB 250 X-ray photoelectron spectrometer. FT-IR spectra were recorded on a Thermo NEXUS 670 transform infrared spectrophotometer (frequency region between 2000 and $600 \mathrm{~cm}^{-1}$ ). Raman spectra were obtained using a T64000 Raman spectrometer with excitation from an argon-ion laser beam $(\lambda=514.5$ $\mathrm{nm}$ ) employing a backscattering geometry.

\section{Results and discussion}

\subsection{Electrocatalytic activity of ERGO toward TTC detection}

The electrochemical behavior of TTC was investigated on
ERGO-0.8V, ERGO-1.2V (GO applied to a negative potential of -0.8 $\mathrm{V}$ and $-1.2 \mathrm{~V}$, respectively), GO, CRGO-modified GC, and bare GC electrodes by $\mathrm{CV}$ in sodium tartrate buffer $(\mathrm{pH}=3.0)$, as shown in Fig. 1. Two pairs of redox peaks were observed for the GC/ERGO-0.8v electrode at 0.2 and $0.3 \mathrm{~V}$ in Fig. 1(f), but the redox peaks at approximately $0.2 \mathrm{~V}$ decreased when the TTC concentration was in the range of $0-1.0 \mathrm{mg} / \mathrm{L}$ (Fig. 1(e)), or more than $10 \mathrm{mg} / \mathrm{L}$. As the TTC concentration was increased, the current of these redox peaks increased, and the separation between the oxidation and reduction peaks became larger. This suggests that these two pairs of redox peaks are related to the electrochemical behavior of TTC. For example, the second oxidation peak at about $0.3 \mathrm{~V}$ shows a good relationship between peak current and TTC concentration in the regions of $0.1-1.0$, $1-10$, and $10-160 \mathrm{mg} / \mathrm{L}$, although the correlation varied in the different concentration ranges. When the TTC concentration is higher than $160 \mathrm{mg} / \mathrm{L}$, the electrochemical signal is unstable. A possible reason for this may be that the electrocatalytic activity was destroyed by the high reaction rate. The cyclic voltammograms of TTC on the GC, GC/ERGO-1.2v, GC/CRGO, and GC/GO electrodes are shown in Fig. 1 (a), (b), (d), and (g), respectively. The bare GC electrode shows an oxidation peak at about $1.2 \mathrm{~V}$, and the GC/ERGO-1.2v electrode shows two oxidation peaks at about 0.7 and $1.2 \mathrm{~V}$ compared with the blank control experiment, which are related to the oxidation of TTC. The GC/GO electrode shows two oxidation peaks at 1.0 and $1.2 \mathrm{~V}$, and the latter disappeared as the concentration was increased. The peak current at $1.0 \mathrm{~V}$ shows a correlation to the TTC concentration only in a limited range of approximately $20-80 \mathrm{mg} / \mathrm{L}$. However, a correlation of the oxidation peak current at $1.0 \mathrm{~V}$


Fig. 1. Cyclic voltammograms of TTC with different concentrations recorded on bare GC (a), GC/ERGO-1.2v (b), GC/ERGO- - $_{\text {.8v }}$ (c, e, and f), GC/CRGO (d), and GC/GO (g) electrodes in a $0.1 \mathrm{~mol} / \mathrm{L}$ sodium tartrate buffer ( $\mathrm{pH} \mathrm{3.0)}$ ) at scan rate of $10 \mathrm{mV} / \mathrm{s}$. Insets of (e), (f), and (g) are curves of TTC concentration $(c)$ versus peak current of (e), (f), and (g), respectively. 
versus TTC concentration on the GC/CRGO electrode was not evident (data not shown). Meanwhile, all of these electrodes did not show a corresponding reduction peak. CV analysis revealed that the electrocatalytic activity of the GC/ERGO- $0.8 \mathrm{~V}$ electrode toward TTC detection was greatly improved compared with the GC, GC/ERGO-1.2v, GC/GO, and GC/CRGO electrodes. At the same time, it should be noted that the background current caused by oxygen evolution exists at the potential region higher than $0.8 \mathrm{~V}$. Hence the potential range of $0-0.5$ $\mathrm{V}$ is more stable and more suitable for the electrochemical detection of TTC. As reported previously, carbon nanotubes, as important nano-carbon nanomaterials, have shown similar electrochemical activities. Comparatively, the potential of the TTC oxidation peak from the carbon nanotube-modified GC electrode $[8,10]$ is about $1.0 \mathrm{~V}$, which is also more positive than that observed from the GC/ERGO-0.8v electrode.

\subsection{Functional group and surface defects analyses}

The FT-IR spectra (Fig. 2) were used to characterize the functional groups on ERGO-0.8v, ERGO-1.2v, GO, and CRGO. A wide band at $3200-3500 \mathrm{~cm}^{-1}$, related to the $-\mathrm{OH}$ stretching vibration, is observed for both GO and ERGOs. Compared with GO, ERGOs exhibited a decrease in the band at $1728 \mathrm{~cm}^{-1}$, corresponding to the $\mathrm{C}=0$ stretching vibration in the carbonyl groups, and the peak at $2930 \mathrm{~cm}^{-1}$ arises from the strong association between carboxyl $\mathrm{C}=\mathrm{O}$ and hydroxyl $\mathrm{O}-\mathrm{H}$ [6]. These signals reflect the lower number of $\mathrm{C}(=\mathrm{O})-\mathrm{OH}$ bonds in $\mathrm{GO}$ after electrochemical reduction. The decrease of the peaks at 1200 and $1054 \mathrm{~cm}^{-1}$, corresponding to hydroxyl $\mathrm{C}-\mathrm{OH}$ vibration, reflects that the number of hydroxyl $\mathrm{C}-\mathrm{OH}$ bonds on ERGO-0.8V decreases after electrochemical reduction. It also exhibits that the $\mathrm{C}=\mathrm{C}\left(1627 \mathrm{~cm}^{-1}\right)$ and epoxy $\mathrm{C}-\mathrm{O}\left(1416 \mathrm{~cm}^{-1}\right)$ peaks of ERGOs become more evident relative to the other peaks originating from oxygen-containing functional groups. Compared with

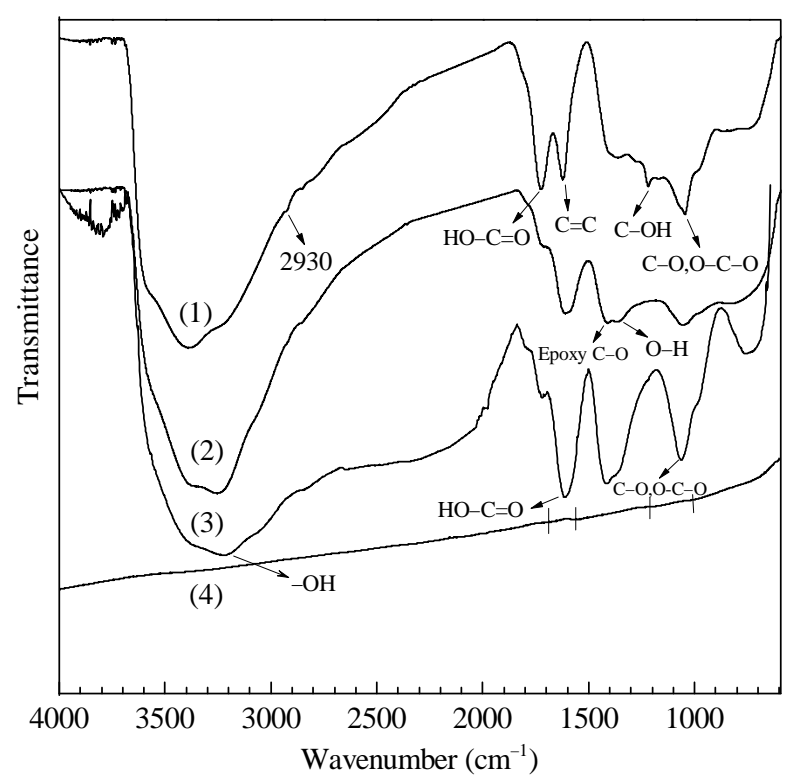

Fig. 2. FT-IR spectra of GO (1), ERGO-0.8v (2), ERGO-1.2v (3), and CRGO (4).

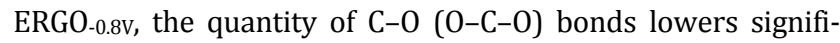
cantly in ERGO-1.2v. In summary, the oxygen-containing functional groups on the ERGO decrease, and the functional groups become less varied but still numerous, which are mainly hydroxyl, epoxy, and carboxyl, while CRGO only shows a few low-intensity bands, such as at 1728, 1200, and $1050 \mathrm{~cm}^{-1}$, corresponding to carboxyl $\mathrm{C}=\mathrm{O}$, hydroxyl $\mathrm{C}-\mathrm{OH}$, and epoxy $\mathrm{C}-\mathrm{O}-\mathrm{C}$ groups, respectively. This reflects that the oxygen-containing functional groups of GO are mostly reduced by chemical reduction.

Figure 3 shows the Raman spectra of ERGO-0.8V, GO, and CRGO. An increased D/G intensity ratio of ERGO-0.8v is observed compared with GO. This change indicates that the electrochemical reduction increases the defect density and decreases the average number of $s p^{2}$ domains. This is because the reduction process created numerous new graphitic domains that were smaller in size than those in GO. However, a much lower $\mathrm{D} / \mathrm{G}$ intensity ratio of CRGO is obtained, which shows that the residual defects cannot be removed, although the oxygen-containing functional groups of GO are mostly reduced by chemical reduction.

XPS was performed on GO, ERGO-0.8v, and ERGO-1.2v to further analyze the change of the oxygen-containing functional groups during electrochemical reduction. As the $\mathrm{C} 1 \mathrm{~s}$ XPS spectra of GO and ERGOs (Fig. 4) show, four deconvoluted peaks at $288.16(\mathrm{O}=\mathrm{C}-\mathrm{O}), 287.5$ (C=0/O-C-0), 286.6 (C-0), and 284.7 $(\mathrm{C}-\mathrm{C}) \mathrm{eV}$ are resolved by fitting the experimental line profile. Comparably, the strong intensity of the three peaks, consistent with oxygen-containing functional groups in both GO and ERGOs, indicates an abundance of oxygen-containing functional groups, such as carboxyl, hydroxyl $\mathrm{C}-\mathrm{OH}$, and epoxy $\mathrm{C}-\mathrm{O}-\mathrm{C}$, still existed after the electrochemical reduction. Comparatively, the amounts of $\mathrm{O}-\mathrm{C}=\mathrm{O}$ and $\mathrm{C}-\mathrm{O}$ decrease and that of $\mathrm{C}=\mathrm{O}$ increases with a negative potential applied to GO, and further shifted from -0.8 to $-1.2 \mathrm{~V}$. The tunability of oxygen-containing functional groups is proposed as follows, in reference to previous research [13]. The amount of $\mathrm{C}-\mathrm{O}$ decreases with the desorption of epoxy and hydroxyl, and carboxyl groups form at the

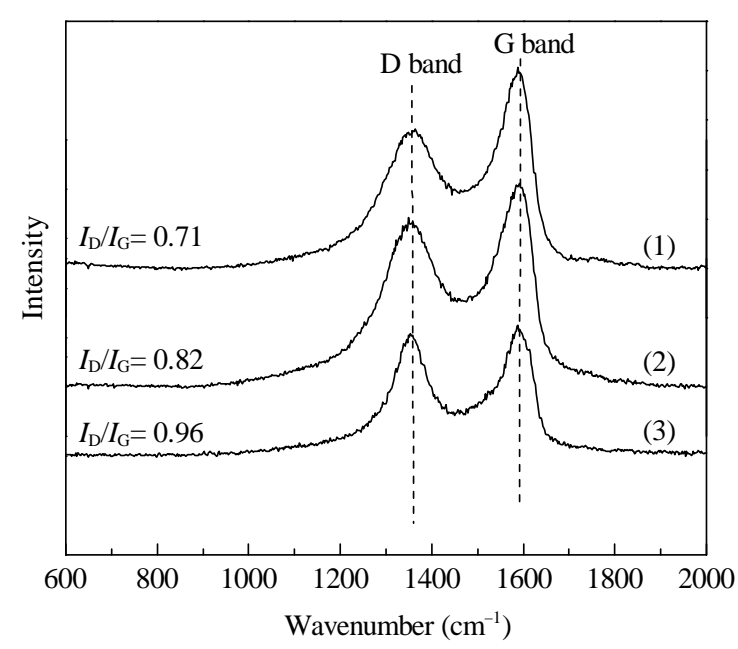

Fig. 3. Raman spectra of GO (1), $\mathrm{ERGO}_{-0.8 \mathrm{v}}$ (2), and CRGO (3). 


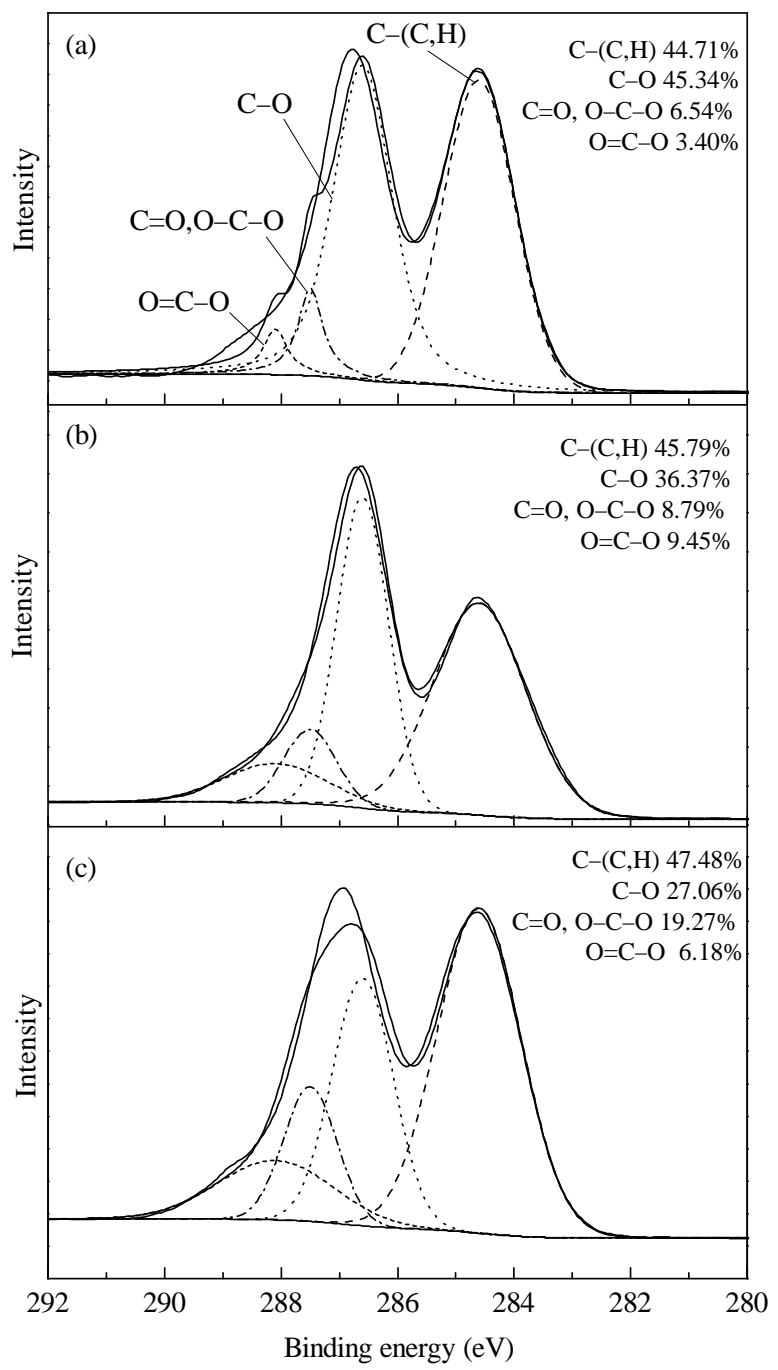

Fig. 4. C $1 s$ XPS spectra of GO (a), ERGO-0.8v (b), and ERGO-1.2v (c).

holes in the reduced GO. Meanwhile, part of the $\mathrm{O}=\mathrm{C}-\mathrm{O}$ was reduced to $\mathrm{C}=\mathrm{O}$ during the electrochemical reduction of $\mathrm{GO}$. Meanwhile, the $\mathrm{C} / 0$ ratios in GO, ERGO-0.8v, and ERGO-1.2v were found to be $1.35,1.69$, and 2.00 , respectively, which reflects that new $s p^{2}$ carbons may form in ERGO, and the reductive degree of GO was increased as the potential became more negative. Combined with the FT-IR results, the quantity of oxygen-containing functional groups decreases as the applied potential is more negative. Therefore, the decrease of oxygen-containing functional groups, especially $\mathrm{O}=\mathrm{C}-\mathrm{O}$ on the edge, is likely to be the main reason for the lowered electrochemical activity of ERGO-1.2v toward TTC compared with ERGO-0.8v. $^{2}$

Physical characterization analyses above demonstrated the stability of carboxyl, hydroxyl $\mathrm{C}-\mathrm{OH}$, and epoxy $\mathrm{C}-\mathrm{O}-\mathrm{C}$ groups during the electrochemical reduction of GO at the potential of $-0.8 \mathrm{~V}$. Therefore, we can correlate the unique electrocatalysis of ERGO toward TTC detection with the adjustment of oxygen-containing groups as the main factor. However, in contrast, GO contains similar functional groups to the ERGO. Thus, the changes in defect density and new $s p^{2}$ domains may also con- tribute to the electrocatalytic behavior of ERGO. It is known that the tunability of the ratio of the $s p^{2}$ and $s p^{3}$ fraction can be a powerful method to tune its bandgap and tailor the electrical, optical and/or chemical properties of GO [14]. Herein, it can be presumed that the tunability of defect density and the $s p^{2}$ domains size could substantially affect the electrocatalytic activity of ERGO.

\subsection{Mechanism analysis}

The redox peaks at $0-0.5 \mathrm{~V}$ on the GC/ERGO-0.8v electrode in blank buffer without TTC (Fig. 1(c)) may have contributed to the transformation between carboxyl $\mathrm{C}=\mathrm{O}$ and hydroxyl $\mathrm{C}-\mathrm{OH}$ groups [29]. Similar redox peaks were also observed on the ERGO-1.2v, GO, and CRGO-modified electrode. When the TTC was added into the buffer solution, the redox reaction of TTC occurred at the potential of $0-0.5 \mathrm{~V}$ on the GC/ERGO- $0.8 \mathrm{~V}$ electrode. Hence, the redox of TTC on the GC/ERGO-0.8v electrode may correspond to the oxygen-containing functional groups transforming between $\mathrm{C}=\mathrm{O}$ and $\mathrm{C}-\mathrm{OH}$. Figure 4 shows that ERGO-1.2v has a greater number of $\mathrm{C}=\mathrm{O}$ groups, but its electrocatalytic activity toward TTC decreases compared with ERGO-0.8v. A possible reason for this is that the newly formed $\mathrm{C}=\mathrm{O}$ bonds occur at the holes in the basal plane [13], where the electron-transfer rate is slow compared with that at the edges [30]. Moreover, the TTC oxidation peak at $1.0 \mathrm{~V}$ is observed for the bare GC (Fig. 1(a)), GC/ERGO-1.2v (Fig. 1(b)), GC/CRGO electrodes (Fig. 1(d)), and GC/GO (Fig. 1(g)) and completely disappeared for the GC/ERGO-0.8v electrode (Fig. 1(c)). This may suggest that the TTC oxidation peak at about $0-0.5 \mathrm{~V}$ on the ERGO-0.8v electrode corresponds to the negative shift of the TTC oxidation potential on GC, ERGO-1.2v, GO, and CRGO, instead of a new electrocatalytic reaction.

As previous studies reported, TTC on a carbon nanotube-modified GC electrode showed an oxidation peak at 1.0-1.8 V, similar to the GC/ERGO-1.2v, GC/GO, and GC/CRGO electrodes [8]. The electrochemical reaction mechanisms, as well as those of phenol [31] and paracetamol [32], were proposed to arise from the structural changes of hydroquinone to quinone. Thus, the redox of TTC at the GC/ERGO electrode may correspond to the transformation between hydroquinone and quinone. A possible mechanism of TTC redox at the GC/ERGO electrode is proposed in Scheme 1.

\section{Conclusions}

This study shows the unique electrocatalytic activity of the GC/ERGO electrode toward TTC detection by electrochemical reduction of GO at $-0.8 \mathrm{~V}$. Physical characterization analyses demonstrated that the oxygen-containing functional groups were adjusted but were still numerous, which are mainly as carboxyl, hydroxyl $\mathrm{C}-\mathrm{OH}$, and epoxy $\mathrm{C}-\mathrm{O}-\mathrm{C}$ groups during the electrochemical reduction of GO at this potential. Meanwhile, the defect density and the size of $s p^{2}$ domains were changed by the formation of new $s p^{2}$ carbons. Therefore, we can correlate the unique electrocatalysis of ERGO with the adjustment of oxygen-containing groups as the main factor, and the defect 


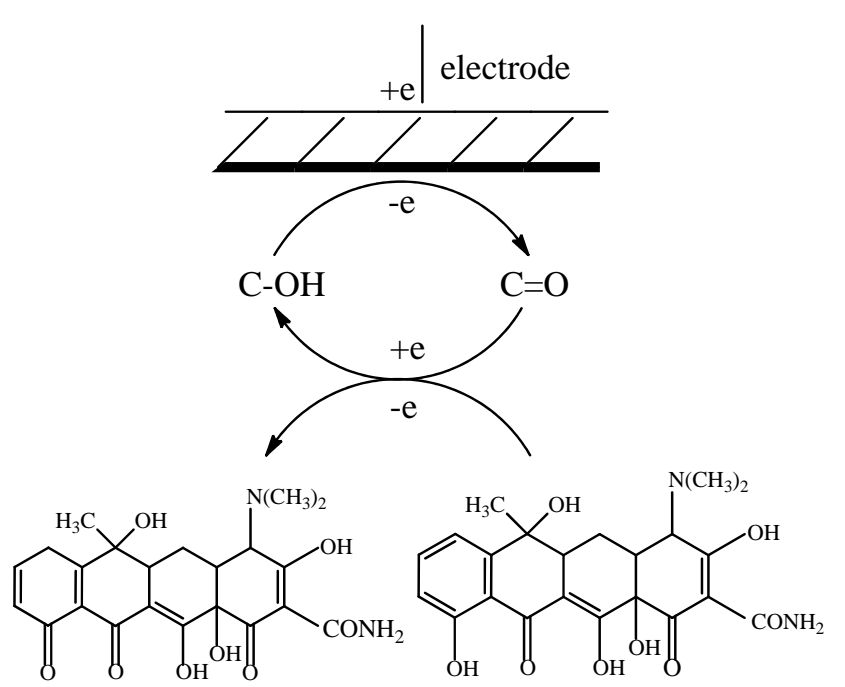

Scheme 1. The possible mechanism of TTC redox at the GC/ERGO electrode.

density and $s p^{2}$ domains also exert a profound influence. The possible mechanism of TTC redox reactions at the GC/ERGO- $0.8 \mathrm{~V}$ electrode is also assumed. This work not only provides a new potential material for TTC electrochemical detection, but also demonstrates that electrochemical reduction is an effective method to establish new catalytic activities for GO with the setting of appropriate parameters.

\section{References}

[1] Richardson B J, Lam P K S, Martin M. Marine Pollut Bull, 2005, 50: 913

[2] Pruden A, Pei R, Storteboom H, Carlson K H. Environ Sci Technol, 2006, 40: 7445

[3] Oka H, Ito Y, Matsumoto H.J Chromatogr A, 2000, 882: 109

[4] Schenck F J, Callery P S. J Chromatogr A, 1998, 812: 99

[5] Zhou M, Wang Y L, Zhai Y M, Zhai J F, Ren W, Wang F, Dong S J. Chemi Eur J, 2009, 15: 6116
[6] Guo H L, Wang X F, Qian Q Y, Wang F B, Xia X H. ACS Nano, 2009, 3: 2653

[7] Loetanantawong B, Suracheep C, Somasundrum M, Surareungchai W. Anal Chem, 2004, 76: 2266

[8] Vega D, Agüí L, González-Cortés A, Yáñez-Sedeño P, Pingarrón J M. Anal Bioanal Chem, 2007, 389: 951

[9] Oungpipat W, Southwell-Keely P, Alexander P W. Analyst, 1995, 120: 1559

[10] Guo G P, Zhao F Q, Xiao F, Zeng B G. Int J Electrochem Sci, 2009, 4: 1365

[11] Wang H T, Zhao H M, Quan X, Chen S. Electroanalysis, 2011, 23: 1863

[12] Shao Y Y, Wang J, Wu H, Liu J, Aksay I A, Lin Y H. Electroanalysis, 2010, 22: 1027

[13] Gao W, Alemany L B, Ci L J, Ajayan P M. Nat Chem, 2009, 1: 403

[14] Loh K P, Bao Q L, Eda G, Chhowalla M. Nat Chem, 2010, 2: 1015

[15] Zhu C Z, Dong S J. Nanoscale, 2013, 5: 1753

[16] Ambrosi A, Bonanni A, Sofer Z, Cross J S, Pumera M. Chem Eur J, 2011, 17: 10763

[17] Wang J F, Yang S L, Guo D Y, Yu P, Li D, Ye J S, Mao L Q. Electrochem Commun, 2009, 11: 1892

[18] Shao Y Y, Wang J, Engelhard M, Wang C M, Lin Y H. J Mater Chem, 2010, 20: 743

[19] Ramesha G K, Sampath S. J Phy Chem C, 2009, 113: 7985

[20] Xu X B, Huang D K, Cao K, Wang M K, Zakeeruddin S M, Grätzel M. Sci Rep, 2013, 3: 1489

[21] Yang T, Li X, Li Q H, Guo X H, Guan Q Jiao K. Polym Chem, 2013, 4: 1228

[22] Yuan B Q, Zeng X Y, Xu C Y, Liu L, Ma Y H, Zhang D J, Fan Y. Sensors Actuat B, 2013, 184: 15

[23] Zhang D J, Xu C Y, Li S J, Zhang R C, Yan H L, Miao H J, Fan Y, Yuan B Q. J Electroanal Chem, 2014, 717-718: 219

[24] Pumera M. Chem Soc Rev, 2010, 39: 4146

[25] Alwarappan S, Erdem A, Liu C, Li C Z. J Phy Chem C, 2009, 113: 8853

[26] Zeng Q Cheng J S, Tang L H, Liu X F, Liu Y Z, Li J H, Jiang J H. Adv Funct Mater, 2010, 20: 3366

[27] Zhou Y F, Zhang G Q, Chen J, Yuan G E, Xu L, Liu L F, Yang F L. Electrochem Commun, 2012, 22: 69

[28] Stankovich S, Dikin D A, Piner R D, Kohlhaas K A, Kleinhammes A, Jia Y Y, Wu Y, Nguyen S T, Ruoff R S. Carbon, 2007, 45: 1558

\section{Graphical Abstract}

Chin. J. Catal., 2015, 36: 1936-1942 doi: 10.1016/S1872-2067(15)60956-1

\section{Electrochemically reduced graphene oxide with enhanced electrocatalytic activity toward tetracycline detection}

Yanyan Xu, Mingming Gao *, Guohui Zhang, Xinhua Wang, Jiajia Li, Shuguang Wang*, Yuanhua Sang

Shandong University, China; University of Warwick, United Kingdom

Electrochemically reduced graphene oxide shows excellent electrocatalytic activity toward tetracycline. The electrochemical reduction is a possible and controllable technique to establish new catalytic activities for graphene oxide.




[29] Noel M, Anantharaman P N. Surf Coatings Technol, 1986, 28: 161

[30] Hallam P M, Banks C E. Electrochem Commun, 2011, 13: 8

[31] Murphy M A, Wilcox G D, Dahm R H, Marken F. Electrochem Com- mun, 2003, 5: 51

[32] Kang X H, Wang J, Wu H, Liu J, Aksay I A, Lin Y H. Talanta, 2010, 81: 754

\title{
电化学还原氧化石墨烯用于四环素电催化检测
}

\author{
胥燕燕，高明明 $\mathrm{a}^{\mathrm{a}}{ }^{*}$, 张国辉 ${ }^{\mathrm{b}}$, 王新华 ${ }^{\mathrm{a}}$, 李佳佳 ${ }^{\mathrm{a}}$, 王曙光 ${ }^{\mathrm{a}, \mathrm{H}}$, 桑元华 ${ }^{\mathrm{c}}$ \\ a山东大学环境科学与工程学院, 山东省水环境污染控制与资源化重点实验室, 山东济南250100 \\ 华威大学化学系, 考文垂CV $47 \mathrm{AL}$, 英国 \\ '山东大学晶体材料国家重点实验室, 山东济南250100
}

\begin{abstract}
摘要: 四环素(TTC)因其广泛的抗菌性和低生产成本等特点而成为应用最广泛的兽医药物. TTC的大量使用不可避免地导致其进 入地表水、地下水和污水处理厂. 迄今, 已有许多方法用于TTC检测, 包括免疫测定法、微生物检测法和化学-物理法等. 然而, 这 些方法费用高, 耗时长或需要复杂的样品预处理过程, 不适合现场测量或常规分析. 电化学分析法具有操作简单、成本低廉、选 择性和灵敏度较高、易实现在线检测等特点, 在检测领域具有重要优势. 石墨烯在电化学传感器领域表现出优越的应用性能, 但 有关石墨烯材料应用于电分析和电催化方面的报道仍然有限. 石墨烯的前驱体氧化石墨烯(GO)片层底面上具有各种类型的含氧 官能团和层状边缘, 导致其绝缘并具有很多缺陷, 使 $\mathrm{GO}$ 包含了 $s p^{2}$ 和 $s p^{3}$ 杂化碳原子, 为 $\mathrm{GO}$ 提供了独特的具有化学功能的异构电子 结构. 通过对GO进行还原, 可以生成新的 $s p^{2}$ 域或者改变含氧官能团的数量和类型, 从而为GO提供更多的特殊性质. 研究表明, 电 化学还原是一种绿色快速的还原方法, 可以控制GO的还原程度和还原过程.

本文利用电化学还原法来调整 $\mathrm{GO}$ 表面的官能团和缺陷度, 利用在 $-0.8 \mathrm{~V}$ 还原电位下得到的电化学还原氧化石墨烯 $\left(E^{2} G_{-0.8 v}\right.$ ) 修饰坡碳电极 (GC) 为工作电极 (GC/ERGO $-0.8 \mathrm{~V}$ ), 采用循环伏安法对溶解在 $\mathrm{pH}=3$ 的缓冲溶液中的TTC进行电化学检测,

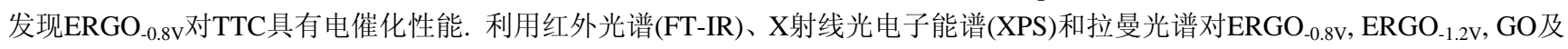
化学还原得到的石墨烯(CRGO)表面官能团和缺陷程度进行了表征, 考察了 TTC在ERGO-0.8v/GC上的电化学行为, 对其电催化还 原机理进行了推测.

结果表明, 与 GO, ERGO-1.2V 及CRGO修饰电极相比, GC/ERGO-0.8v修饰电极的催化还原峰在0-0.5 V, 对TTC表现出独特的电 催化性能, GC/ERGO-0.8v 电极对浓度为 $0.1-120 \mathrm{mg} / \mathrm{L}$ 的TTC溶液具有良好的检测性能, 在不同浓度范围内其氧化峰峰电流与峰电 位的线性关系不同. FT-IR和XPS结果显示, 在 -0.8 V 还原电位下得到的ERGO $-0.8 \mathrm{~V}$, 其官能团类型和数量发生变化, 但仍存在大量 官能团, 主要是羧基、羟基和环氧基. 同时, 拉曼表征显示 $\mathrm{ERGO}_{-0.8 \mathrm{~V}}$ 的缺陷密度增大, 同时新生成的 $s p^{2}$ 域减小而使得ERGO的 $s p^{2}$ 域减小. 对比GO等其他材料的表征结果推测, 官能团变化是影响ERGO独特电催化性质的主要因素, 除此之外还有材料的缺陷度 和 $s p^{2}$ 域. 推测GC/ERGO- $0.8 \mathrm{v}$ 修饰电极对TTC可能的催化机理为: TTC在GC/ERGO电极上的还原与氢醌和醌之间的转换有关; 而 对于ERGO, 则可能对应于羧基和羟基之间的转化. 然而, 同样具有羧基和羟基的ERGO-1.2v 则对TTC没有产生电催化作用. 其原 因可能是在 -0.8 到 $-1.2 \mathrm{~V}$ 还原电位下, 形成的羧基位于石墨烯片层内部, 而片层内的电子传递较慢.
\end{abstract}

关键词: 电化学还原氧化石墨烯; 电化学检测; 电催化性能; 四环素; 含氧官能团

收稿日期: 2015-04-23. 接受日期: 2015-07-03. 出版日期: 2015-11-20.

*通讯联系人. 电话: (0531)88362802; 传真: (0531)88364513; 电子信箱: mmgao@sdu.edu.cn

通讯联系人. 电话: (0531)88362802; 传真: (0531)88364513; 电子信箱: wsg@sdu.edu.cn

基金来源：国家自然科学基金(21007033); 山东大学基本科研业务费专项资金(2015JC017).

本文的英文电子版由Elsevier出版社在ScienceDirect上出版(http://www.sciencedirect.com/science/journal/18722067). 